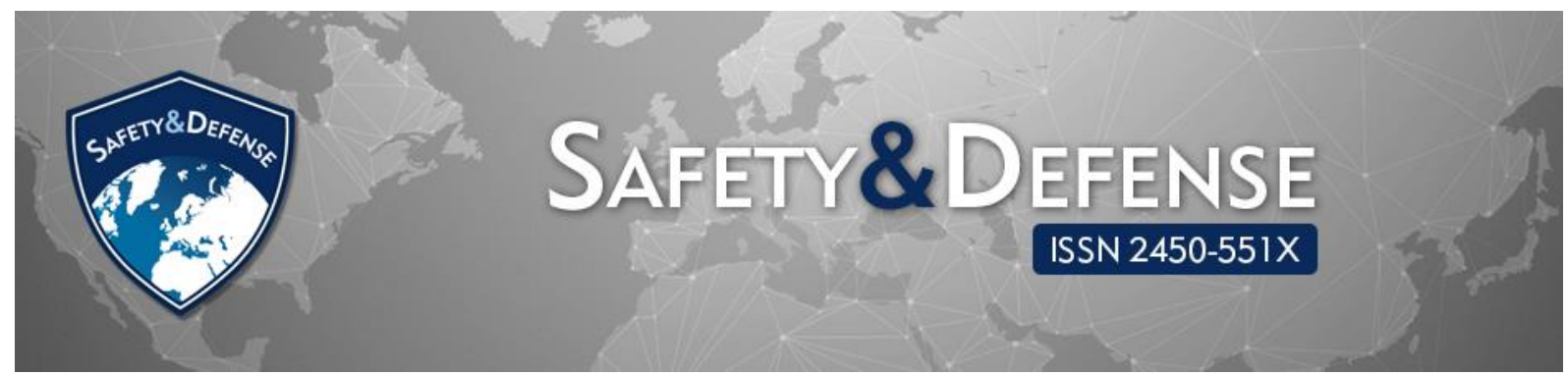

\title{
The Influence of the Russian Federation on Poland's Energy Security
}

\author{
Klaudia STACHOWIAK ${ }^{1}$ \\ ${ }^{1}$ War Studies University, Warsaw, Poland, e-mail: k.stachowiak@akademia.mil.pl \\ ORCID: 0000-0002-0389-7437
}

DOI: https://doi.org/10.37105/sd.74

\begin{abstract}
Energy security is a key element of national security. It is difficult to formulate a proper structure for strategic culture or political strategy without considering this key element. Therefore, it is necessary to discuss particularly important factors shaping the Polish security policy: diversification of energy ties, adaptation of the national technical infrastructure to contemporary requirements of the raw materials market, and bilateral and multilateral agreements on energy security problems. The influence of the Russian Federation plays an important role in Poland's energy security policy. Bilateral relations in the energy sector affect Poland's energy security and foreign policy. They also affect Poland's internal policy and, therefore, should be regarded as crucial for the Polish national interest.

The research problem of the paper used by the author is: How and by what means, methods, techniques, and forms does the Russian Federation influence Poland's energy security and what consequences does this have for our country? The aim of the paper is to present the state of Poland's energy security and the desirable prospects in the relations with the Russian Federation in the context of natural gas and crude oil supplies. This paper uses such research tools as analysis, synthesis, comparison, and inference to determine Poland's current energy.
\end{abstract}

Keywords: crude oil, natural gas, Poland, Russian Federation, security. 


\section{Introduction}

Poland's relations with the Russian Federation in the energy sector are often compared to political relations between Warsaw and Moscow. In spite of the three decades since Poland regained full sovereignty, it has been impossible to establish relations with our eastern neighbor that are based on the internationally accepted free market rules and respect of rights and freedoms. Both parties are responsible for this situation. The reasons that have contributed to the formation of bad bilateral relations include problems with interpretation of historical events, resentment, different views on the functioning of the European security system, and conflicting political and economic interests in Central and Eastern Europe (Weremiuk, 2015). The Polish side accuses the Russian Federation of interference of the Russian secret services in Polish-Russian relations in the sphere of energy (Mitraga, 2013). What is also important is the use of natural gas and crude oil by Russia as effective tools for creating international relations (Zygar, and Paniuszkin, 2008). Reality shaped in this way negatively affects the Polish fuel market, which, despite the implementation of some of the energy projects aimed at diversifying both the sources of supply of raw materials and their transmission routes, has lost its importance. The role played by our energy sector in the European fuel market is relatively small. The new routes for the transmission of raw materials launched by the Russian Federation exclude the Poland from the transit of crude oil and natural gas, while time reducing the Polish government's negotiating power in relation to its Russian partner. An energy policy defined in this way also translates into our country's position in the European fuel market. Polish energy consortia do not participate in major energy projects implemented by some European countries with the Russian Federation. Efforts to pursue Poland's own energy policy in isolation from the reality of the European fuel market are bound to end in failure. At present, the Polish government, failing to achieve success in the European fuel market, is concentrating on ensuring Poland's energy security, which is too little for the ambitions of our energy sector.

The research problem of the paper is: How and by what means, methods, techniques, and forms does the Russian Federation influence Poland's energy security and what consequences does this have for our country? The aim of the paper is to present the state of Poland's energy security and the desirable prospects in the relations with the Russian Federation in the context of natural gas and crude oil supplies. This paper uses such research tools as analysis, synthesis, comparison, and inference to determine Poland's current energy. This paper presents the directions Poland's supply with natural gas and crude oil, the forms of Poland's energy cooperation with the Russian Federation, and the projects aimed to diversify the sources and routes of energy resources in which Poland participates. The analysis carried out in this way made it possible to formulate the conclusions presented herein.

\section{Energy potential of the Republic of Poland}

Poland does not have strategically important natural gas and crude oil resources that would ensure the country's energy selfsufficiency. The documented natural gas deposits are estimated at $127 \mathrm{bcm}$. Their rational use would enables covering 25-30\% of the needs of businesses and consumers. The rest of the natural gas needed must be imported from abroad (Kaliński et al., 2010). Some hopes have been associated with the exploitation of shale gas deposits. Initially, they were estimated at nearly five trillion cubic meters. However, a thorough analysis of the shale gas deposits showed that the initial calculations were too optimistic. According to experts' declarations, the current estimated volume of shale gas deposits in Poland does not exceed 150-300 bcm. Shale gas 
deposits are difficult to access. At this stage of the development of extraction technology, exploitation of shale gas deposits in Poland seems unprofitable. According to experts from the gas industry, it will take 10 to 20 years until some of the shale gas deposits in Poland can be exploited. However, this will depend on the size of the deposits, their location, and finally their accessibility (Górecki et al., 2010). The crude oil extraction industry is of much more limited importance for the Polish economy than the refining sector. Poland's crude oil resources are small. The annual production of crude oil varies between 0.8 and 0.9 million tons, with the market demand equal to nearly 25 million tons. Polish crude oil deposits are located in the Carpathian Mountains, the Polish Lowlands, and the Baltic Sea (infolupki.pgi.gov.pl, 2014). Poland is forced to import most of its crude oil from abroad, mainly from the Russian Federation. Russian crude oil goes to Poland via the Druzhba pipeline and is shipped in tankers to crude oil terminals. Poland has one of the largest European resources of hard coal, amounting to 51 billion tons, and lignite coal, amounting 23 billion tons (Szuflicki et al., 2015). However, the pro-duction of hard coal in our country arouses serious controversy. The process of hard coal extraction from deposits is expensive and its use in the production of electricity and heat arouses great controversy among the climate advocates. A majority of countries with hard coal deposits are giving up its use in favor of heat and electricity production from alternative, much more environmentally friendly sources. Currently, in the Polish energy system biomass and biogas installations have a capacity of about 1 $400 \mathrm{MW}$. This gives them the second place (after windmills) in the renewable energy sector in this respect. Installations are responsible for approximately $35 \%$ of electricity production in this segment. On the other hand, wind energy generates about $55 \%$ of electricity from Polish renewable sources (Szadkowski, 2015).

\section{Directions of supply of natural gas and crude oil to Poland}

Natural gas and crude oil are supplied to Poland from the Russian Federation and, to a lesser extent, from other European countries. Currently, supplies can be made through the gas network running from Russia through the territory of Ukraine and through the Yamal pipeline, the route of which runs across the territory of Belarus. Poland is both a consumer of natural gas and a transit country. In 2016, Poland started to receive deliveries of natural gas using the gas terminal in Świnoujście. It is suitable for receiving liquefied natural gas (LNG). Currently, the terminal is capable of processing nearly $5 \mathrm{bcm}$ of natural gas annually. There are plans to expand it in order to increase its capacity to $7.5 \mathrm{bcm}$ of gas per year. Currently, the terminal's capacity is used at about $60 \%$. Poland receives liquefied natural gas deliveries from Qatar. However, it is possible to buy gas from other sources, including Algeria and even the Russian Federation. Prices of liquefied natural gas are currently similar to those of the natural gas transmitted conventionally through pipelines. The problem, however, is the frequent fluctuation of prices on the LNG market, due to lack of long-term contracts, which are more resistant to the conditions of the global fuel market. There are also technical problems with the transport of LNG due to the too shallow navigation channel connecting the Baltic Sea with the gas terminal, which makes it impossible to accept LNG carriers with the capacity of over 300 thousand GRT. The price of LNG is also increased by the lack of Poland's own fleet of LNG carriers, which makes it necessary to lease them or to ask the LNG producer to deliver LNG, which ultimately affects the final transaction costs (Maciążek, 2015). While the cost-effectiveness of this investment is questionable from an economic point of view, in terms of energy security, the strengthening of Poland's bargaining position in the negotiations of gas contracts with the Russian Federation cannot be underestimated. Poland also has 
the possibility to receive natural gas through a system of interconnectors between Poland, Germany, and Slovakia. There were some hopes for a local gas connection with Ukraine, which has deposits in the Carpathians and Podolia (Klaczyński, 2010). Ukraine's problems in the international arena, as well as its unstable internal situation, have hindered this project. At present, natural gas is transmitted from Poland in the opposite direction to the intended one - to Ukraine. Poland also has a well-developed, partially modernized network of natural gas storage facilities. The quantity of natural gas stored in storage facilities corresponds to Poland's demand in nearly two months (www.osm.pgnig.pl, 2016).

\section{Polish-Russian cooperation in the energy sector}

Russia sells natural gas to Poland under long-term contracts. Poland pays a relatively high price for the imported natural gas, which is a result of its still weak negotiating position. With the improvement of Poland's energy security, e.g. through the implementation of new investments diversifying the direction of natural gas supplies, Russia has become much more willing to make concessions than it was before, which has resulted in the reduction of the price. On the other hand, the reduction in the price of the natural gas bought by Poland is also the result of the downward trend in the global natural gas market. The aim of the Polish government is to reduce the import of natural gas from the Russian Federation, which is to contribute to a reduction of Poland's energy dependence. The political factor plays a major role in this regard. Poland aims to be an independent player in the region of Central and Eastern Europe and encountering strong opposition from the Russian Federation, which is Poland's competitor in such foreign policy. Too much dependence on natural gas supplies from Russia weakens Poland's negotiating position (Toś, 2010). The costs of this policy in the area of energy security and the stability of supplies from the countries of the Middle East remain a problem, especially in view of the ongoing socio-political changes in that region, which are anti-Western in nature. The rules according to which Russia supplies natural gas to Poland also remain not entirely transparent. This gives rise to numerous controversies and frequent disputes that are resolved either by Russian courts or by the competent court of arbitration (wgospodarce.pl, 2015). However, it is difficult to imagine that cooperation with Russia in the supply of crude oil and gas to Poland would stop in the future. For the Russian Federation, Poland remains an important buyer of natural gas and crude oil. For Poland, Russia continues to be the most advantageous source of supply in terms of stability and price. A problem in Polish-Russian relations in the energy sector remains the issue of transit of natural to Europe by the Russian Federation. Russia strives to build alternative routes of natural gas transit excluding the participation of Central and Eastern European countries, including Poland, from the transit of this energy source. In the mid1990s, Russia strove to establish the transit of natural gas through Poland to the European market, through the Yamal I and Yamal II systems which bypassed Ukraine. For geopolitical reasons, Poland refused to participate in the Yamal II project, thus reducing its importance as a transit country. The Russian Federation has found an alternative to Yamal II in the form of construction of the Nord Stream gas pipeline (Kardaś, 2013). It is currently trying to implement the Nord Stream II Project, which would limit the share of Central and Eastern European countries in the transit of Russian natural gas to an absolute minimum or even exclude these countries from the transit altogether (Dąbrowski et al., 2015). The Russian-German cooperation in the construction of the new gas connections, the technical infrastructure in the form of natural gas storage facilities, and the high-capacity reduction stations in Germany raises serious concerns among Polish politicians and experts (Nitoiu, 2014). The position of Poland as a 
transit country is clearly weakening. It seems that the Russians are close to completion of their projects. Paradoxically, therefore, both countries share a desire for deep diversification of gas connections, but Poland wants to implement projects that exclude Russia and Russia does not see any place for Poland in its projects. The decisive factor is that geopolitics and economic factors are being pushed into the background. The problem in Polish-Russian relations in the energy sector remains the issue of crude oil supplies to the terminals in Gdańsk and Płock. The Russian Federation delivers crude oil by tankers from its terminals in Primorsk and Ust Luga, where crude oil delivered by the BTS 1 and BTS 2 installations, which reduces Poland's share in the transit and refining of the material. Thus, Russia has acquired the opportunity to transport crude oil by sea without the need to bind itself to a specific contractor for long-term contracts, and will not have to pay for transit of the material (osw.waw.pl, 2012). In these circumstances, Poland's negotiating position in relation to Russia is clearly weakened. Prices of crude oil transported by sea are higher than those delivered through pipeline systems. Poland is also losing out due to the lack of crude oil transit. The Russian Federation also acquired the possibility to freely choose the counterparties for the supply of crude oil, to the detriment of Poland's energy security. The so-called Baltic pipeline system has clearly strengthened Russia's position on the European fuel market at the expense of countries of Central and Eastern Europe. Another problem for Poland, related to the Russian crude oil supply system, is the situation of the refinery in Mažeikiai, Lithuania (Kublik, 2016), which is owned by the Płock refinery. The Russians interrupted the supply of crude oil through the internal crude oil pipeline system, in return offering more expensive, burdensome deliveries by sea to the port of Klaipeda, from where crude oil is transported by rail to the refinery in Mažeikiai. As a result, this refinery makes losses for the Polish company (polskieradio.pl, 2016). Polish-Russian cooperation in the energy sector is limited to issues related to the transit and sale of crude oil. The Russian Federation would probably be interested in purchasing a block of shares in Polish crude oil refineries and the LNG terminal, which, however, is currently not permitted by the Polish state. Poland's energy security strategy excludes the possibility of further dependence on the Russian counterparty and Polish politicians are trying to reduce the existing contacts in the energy sector to the necessary minimum. Discussions on cooperation in the energy sector often take a technical form. In such a situation, it is difficult to talk about the possibility of implementation of strategic plans. This is to the detriment of both the Polish state and the Russian Federation itself Poland is not strengthening its position in the European energy market and, unfortunately, is becoming a peripheral part of it, despite the increased purchasing possibilities and the emergence of new alternative routes for their transit. Without participating in major energy projects, which was possible in the case of Yamal II and Nord Stream, Poland's involvement in shaping the European fuel market is limited to attempts to negate facts. The emerging concepts of construction of joint gas power plants in Poland are unfortunately blocked for political reasons. The history of mutual relations, prejudice, and politics continue to have a greater impact than the economic dimension of the relations between the two countries (Ruszel, 2015).

\section{Projects for the diversification of Poland's natural gas and crude oil sources and transit routes}

Poland is striving to implement gas connection projects and to establish new crude oil transit routes without Russia's involvement. The main objective is to weaken the position of the Russian Federation in the European fuel market. Hence, the desire to implement an energy solidarity project that would place the European Union as a single entity representing its member states. This 
would strengthen the EU's negotiating position vis-à-vis Russia, force the latter to comply with the standards set by the European Energy Charter, and gain the opportunity to reduce prices for the materials. However, key EU countries, such as Germany, Italy, and France, apart from declaring the need for a common energy policy, are not implementing specific projects associated with it. This is due to their desire to maintain good relations with the Russian Federation and the possibility of profiting from cooperation with the Russian partner in the energy sector (Kaczmarski, 2010). While the construction of the gas terminal in Świnoujście, the expansion of the network of natural gas storage facilities, and the adoption the energy policy expressed in the implementation of successive interconnectors increasing Poland's energy security, finally have their real conditions, some of the projects to be implemented by the Polish government should be considered as projects of low credibility. One such project was the White Stream. Natural gas was to flow from the Azeri deposits through Georgia and the Crimean Peninsula in the Black Sea, to EU countries (Kaczmarski, 2011). Poland was to receive natural gas through a network of interconnectors. The difficulties associated with the implementation of the project proved insurmountable already at the design stage. However, some Polish fuel market experts continue to consider similar projects, heating up the atmosphere related to Poland's energy security. This has a negative impact on Polish-Russian relations in the energy sector and makes constructive dialogue difficult. It also seems that Poland is not well aware of the geopolitical realities governing the energy market in the Caspian basin countries. This is an indication of poor substantive preparation on the part of both decision-makers responsible for the Polish fuel market and officials of the Ministry of Foreign Affairs responsible for international relations. Greater hopes may be placed on the launch of the Transanatolian (TANAP) gas pipeline connecting the Azeri Shah Deniz two gas fields with Turkey, which intends to sell Azeri natural gas in the southern European fuel market. This project, which is part of the Southern Gas Corridor, is aimed to diversify supply and reduce the dependence on Russia in terms of purchase of energy materials (Forbes.pl, 2018). The Polish government sees this as an opportunity for supplying natural gas through a network of interconnectors to Poland. The advisability of such a diversification is questionable, especially considering the economic aspect. It should also be presumed that the investment carried out by Azerbaijan and Turkey will compensate Russian interests, which has always been an obstacle for the Polish government's participation in such projects. So far, in such situations, politics has always taken precedence over real interests. Another example of the Polish government's ineffective energy policy was its involvement in the Amber gas pipeline project connecting the Baltic States with Poland. It was to be an effective alternative to the Russian Nord Stream pipeline. The assumption was that natural gas from the Russian Federation would flow through the Baltic States and Poland to Western Europe. In the absence of consent from the Russian government, Amber was to be an extension of the installation for the Baltic Pipe, from where Norwegian gas would be supplied to countries of Central and Eastern Europe. This project never went beyond the study phase (rp.pl, 2014). Construction of the OdessaBrody-Gdańsk connection, in view of the lack of a potential source of crude oil supply, the difficulties in delineating the route, not to mention the technical aspects of the pipeline's construction, should be regarded as a kind of political game played increasingly for internal use. It is difficult for such ideas to arouse the interest of serious players in the European fuel market (Kresy24.pl, 2016). The construction of a gas connection with Norway, from where Poland would like to import about $8 \mathrm{bcm}$ of natural gas per year, is also unlikely. This quantity is too small for this project to be cost-effective. So far, attempts to attract other partners for the project from Central and Eastern Europe have failed. As a result, the project was suspended. In 2016, for political rather than 
economic reasons, the government decided to return to the plan to build a gas connection with Norway. For the time being, however, apart from the declarations, there are no more serious details which would indicate the possibility of implementing this project in the future (Kresy24.pl, 2016). Instead, small investments of local importance are being made. These include the construction of the Hermanowice-Bliche Volytsia interconnector to connect the Polish transmission system with the Ukrainian gas installations. This gas pipeline, planned for this year, will be of greater importance for the Ukrainian partner, who will be able to receive supplies from Poland without the involvement of the Russian Federation. The transmission capacity of the installation has been defined in the project as $20 \mathrm{bcm}$ per year. This investment project will not significantly affect the energy security of our country. It is difficult to expect supplies of Ukrainian natural gas in the foreseeable future, while the country continues to be an importer and does not have adequate funds to exploit its own deposits. It is rather a kind of manifestation of Polish-Ukrainian solidarity towards the Russian partner (Gaz-system.pl, 2015, 2016).

\section{Conclusion}

In view of the above, it can be concluded that the Russian Federation will continue to have a major impact on Poland's energy security. At the same time, the political factor will continue to govern Polish-Russian relations in the energy sector. The change in Russia's energy strategy, namely the reorientation of crude oil and gas supplies from the European fuel market to the Asian energy commodity market, can also be of some importance. Although this is a long-term process, some mechanisms have been put in place by the Russian Federation (Kardaś, 2016). Both Russia and Poland perceive the energy sector as an element of a game, a tool for creating and influencing international relations. The question of possible economic gains is considered as one of secondary importance. This does not bode well for future Polish-Russian relations in the energy sector. In the next few years, Poland will continue its efforts to reduce the Russian share in the domestic natural gas and crude oil market. A strategy defined in this way, one that is dependent on the political factor, seems to be possible only at the expense of economic aspects, which will adversely affect the competitiveness of Polish companies. The Russian Federation is a dominant party in the European fuel market. This state of affairs will not change quickly due to the interest of many Western countries in maintaining good economic relations with Russia in the energy sector. The relations of Germany, Italy, and France with the Russian Federation are to a much lesser extent burdened with political problems resulting from a difficult, complicated history related to Russian domination, as is the case in Poland. The fear of the latter, unfortunately, precludes the possibility of rational behavior. Certain political, historical, and - last but not least - social processes must come to an end in order to establish good mutual relations in the energy sector. Such relations would be based on economic rather than, as is currently the case, political grounds.

\section{References}

1. Dąbrowski, T., et.al. (2015). Europa Środkowa i Południowo-Wschodnia wobec projektu Nord Stream. Osw.waw.pl, 14.10.2015. Retrieved from https://www.osw.waw.pl/pl/publikacje/analizy/2015-10-14/europa-srodkowa-i-poludniowo-wschodnia-wobecprojektu-nord-stream-2, 30.06.2019.

2. Duszczyk, M., Orlen prowadzi rozmowy z rzadem Litwy na temat rafinerii $w$ Możejkach. Retrieved from 
http://www.polskieradio.pl/42/3167/Artykul/1597572, 30.04.2019.

3. Frobes.pl. (2018). Turcja uruchomila gazociąg TANAP. Azerski gaz bliżej Europy. Forbes.pl, 18.06.2018. Retrieved from https://www.forbes.pl/gospodarka/turcja-uruchomila-gazociagtanap-azerski-gaz-blizejeuropy/m59ozbk, 18.05.2019.

4. Gaz-system.pl. (2015). Gaz System SA oraz PJSC Ukrtransgaz opracowaty studium wykonalności dla połączenia międzysystemowego Polska-Ukraina. Gaz-system.pl, 19.10.2015. Retrieved from http://www.gaz-system.pl/centrum-pra-sowe/aktualnosci/informacja/artykul/202160/, 12.05.2019).

5. Górecki, W., et al. (2010). Perspektywy poszukiwań niekonwencjonalnych złóż gazu ziemnego. Retrieved from http://yadda.icm.edu.pl/baztech/element/bwmeta1.element.baztech-articleBSL9-0045-0002, 30.06.2019.

6. Groszkowski, J. (2015). Czesi wobec Nord Stream 2. Retrieved from https://www.osw.waw.pl/pl/publikacje/analizy/2015-12-09/czesi-wobecnord-stream-2, 30.06.2019.

7. Gaz-system.pl. (2016). Interkonektor Polska-Ukraina. Gaz-system.pl, 08.12.2016. Retrieved from http://www.gaz-system.pl/nasze-inwestycje/integracja-z-europejski-systemem/interkonektor-polska-ukraina/, 12.05.2019.

8. Infolupki.pgi.gov.pl. Available online http://infolupki.pgi.gov.pl/ropanaftowa/aktulanosci/ropa-naftowa-wPolsce.html, 15.05.2019.

9. Kaczmarski, M. (2010). Bezpieczeństwo energetyczne Unii Europejskiej. Warsaw: Łośgraf.

10. Kaczmarski, M. (2011). Which rules for the global order? The global dimension of the Russian-EU relationship - the case of international crises, Journal of Contemporary European Reaserch, 7(2), 159174.

11. Kaliski, M., et al. (2010). Gaz ziemny w Polsce - wydobycie, zużycie i import do
2030 roku. Górnictwo i Geologia 5(3), pp. 27-40.

12. Kardaś, Sz. (2013). Rosja reaktywuje Jamat 2: kolejny bluff czy realny projekt? Retrieved from, https://www.osw.waw.pl/pl/publikacje/analizy/2013-04-10/rosja-reaktywuje-jamal-2-kolejny-bluff-czy-realnyprojekt, 30.06.2019.

13. Kardaś, Sz. (2013). Wspótzależność energetyczna Europy i Rosji się utrzyma. Retrieved from https://biznesalert.pl/kardas-wspolzaleznosc-energetycznaeuropy-i-rosji-sie-utrzyma/, 12.01.2020.

14. Kardaś, Sz. (2016). Zacieśnianie rosyjsko-indyjskiej wspótpracy energetycznej. Retrieved from https://www.osw.waw.pl/pl/publikacje/analizy/2016-06-22/zaciesnianie-rosyjsko-indyjskiej-wspolpracy-energetycznej, 12.05.2019.

15. Kłaczyński, R. (2015). Ropa naftowa $i$ gaz ziemny obszaru postradzieckiego. Rola $i$ znaczenie surowców energetycznych $w$ polityce Kremla. Kraków: WNUP.

16. Kresy24.pl. (2016). Azerbejdżan i Ukraina reanimują projekt ropociągu Odessa-Brody. Kresy24.pl, 15.11.2016. Retrieved from http://kresy24.pl/azerbejdzan-i-ukrainareanimuja-projektrurociagu-odessabrody/, 30.06.2019.

17. Kresy24.pl. (2016). Polska zbuduje gazociąg z Norwegii! Koniec zależności od Rosji. Kresy24.pl, 29.01.2016. Retrieved from http://kresy24.pl/polska-zbudujegazociag-z-norwegii-konieczaleznosciod-rosji/, 30.06.2019).

18. Kublik, A. (2016). Gazociąg nas podzieli, Gazeta Wyborcza, 13.09.2016, p. 8.

19. Kublik, A. (2008). Kaspijski gaz zmierza do Polski, Gazeta Wyborcza, 30.08.2008, p. 18.

20. Maciążek, P. (2015). Pierwsza dostawa katarskiego LNG dotarka do Polski. Retrieved from http://www.energetyka24.com/281495,pierwszadostawa-katarskiego-lngdotarla-do-polski 12.01.2019. 
21. Mitręga, A. (2015). Aktywność pol-skich i rosyjskich służb specjalnych w kształtowaniu bezpieczeństwa energetycznego. Studia HumanistycznoSpołeczne, 7 (2013), pp.109-123.

22. Nafta.wnp.pl. (2012). Putin uruchomił ropociąg BTS 2 alternatywę wobec Przyjaźni. Nafta.wnp.pl, 23.03.2012. Retrieved from http://nafta.wnp.pl/putinuruchomil-ropociag-bt-2-alternatywewobec-Przyjazni, 16.02.2019.

23. Nitoiu, C. (2014). EU-Russia rela-tions: Between conflict and cooperation, Internalional Politics, 51(2), pp. 234-253.

24. Osm.pgnig.pl. Available online http://www.pgnig.pl/pl/magazyny, 12.01.2020.

25. Osw.waw.pl, (2012). BTS 2 uruchomiony w trybie testowym. Osw.waw.pl, 28.03.2012. Retrieved from https://www.osw.waw.pl/pl/publikacje/analizy/2012-03-28/rosja-bts-2uruchomiony-w-trybie-testowym, 30.06.2019.

26. Rp.pl. Available online http://www.rp.pl/artykul/90618-Rosja-gazociag-Amber-nie-jest-alternatywawobec-Nord-Stream.html\#ap-1 15.05.2019).

27. Ruszel, M. (2010). Polsko-rosyjskie rozmowy energetyczne. Retrieved from http://www.stosunki.pl/?q=connent/polsko-rosyjskie-rozmowy-energetyczne.html, 20.02.2019.

28. Szadkowski, S. (2015). Schyłek epoki węgla $w$ Polsce. Wydobycie węgla w Polsce nie ma racji bytu. Retrieved from http://dzien-

nikzachodni.pl/artykul/3903397,schylek -epoki-wegla-w-Polsce-wydobycie-weglaw-Polsce-nie-ma-racji-bytu.html, 16.02.2019.

29. Szczesniak.pl. (2011). Przyjaźń będzie wysychać, Naftoport przestanie zarabiać. Szczesniak.pl, 24.11.2011. Retrieved from http://szczesniak.pl/2035b, 30.06.2019.

30. Szczesniak.pl. Available online http://www.szczesniak.pl/1078, 18.10.2018.

31. Szuflicki M., et al. (2015). Bilans zasobów złóż kopalin w Polsce według stanu na 31 grudnia 2014, Warszawa: Polski Instytut Geologiczny.

32. Toś, A. Polityka Polski $w$ zakresie dywersyfikacji dostaw gazu ziemnego. Ocena rozwiazań. Retrieved from http://www.psz.pl/118-gospodarka/polityka-polski-w-zakresie-dywersyfikacjidostaw-gazu-ziemnego-ocena-rozwiazan, 10.05.2019.

33. Weremiuk, S. (2015). Polska wobec Rosji w latach 1992-2014. Od zależności postimperialnych do trudnych relacji. Analiza wybranych aspektów. Przegląd Bezpieczeństwa Wewnętrznego, 13(7) 2015, pp. 99-120.

34. Wgospodarce.pl. (2015). PGNiG wezwało Gazprom do Trybunału Arbitrażowego w sprawie cen gazu z Syberii do Polski. Wgospodarce.pl, 14.05.2016. Retrieved from http://wgospodarce.pl/informacje/1987-o-pgnig-wezwalo-gazprom-do-trybunalu-arbitrazowego-w-sprawie-cen-gazu-zsyberiidla-polski, 12.12.2019.

35. Wyciszkiewicz, E. (2008). Rosyjska polityka energetyczna $\mathrm{w}$ basenie Morza Kaspijskiego. In F. Wyciszkiewicz E. (Ed.), Geopolityka rurociągów. Współzależność energetyczna a stosunki międzypaństwowe na obszarze postsowieckim, pp. 137-156 Warszawa: PISM.

36. Zygar, W., Paniuszkin, W. (2008). Gazprom: rosyjska broń. Warszawa: WAB. 